\title{
Epigenetic changes: a common theme in acute myelogenous leukemogenesis
}

\author{
Soraya E Gutierrez ${ }^{1,2^{*}}$ and Francisco A Romero-Oliva ${ }^{2}$
}

\begin{abstract}
Acute myeloid leukemia (AML) is a rather common disease, characterized by the presence of a clonal population of hematopoietic progenitor cells with impaired differentiation. Although traditionally AML has been considered the result of genetic alterations, more recently experimental evidence have demonstrated that epigenetic modifications are important in development and maintenance of leukemia cells. In this review we summarize current scientific knowledge of epigenetic alterations involved in leukemogenesis. We also highlight the developing of new technological strategies that are based on epigenetic processes and have been registered as Patents of Inventions in the United Nations dependent World Intellectual Property Office (WIPO) and the main Patent offices worldwide.
\end{abstract}

\section{Introduction}

The World Health Organization (WHO) defines acute myeloid leukemia (AML) as a heterogeneous clonal disorder of hematopoietic progenitor cells ("blasts"), which exhibit impaired maturation [1]. AML is the most common acute leukemia in adults and, in the absence of treatment, this alteration in blood cells leads to dead typically within 1 year of diagnosis mainly by infection, bleeding, or organ infiltration. Until now, treatment of AML consists of cytotoxic "chemotherapy" and might cure $20-75 \%$ of patients younger than 60 years depending primarily on leukemia-cell cytogenetics. However, in elderly patients despite achievement of reasonable complete response rates (CR rates 35\%-55\%), intensive chemotherapy is associated with a high incidence of 4-week mortality and with 3 - to 5 -year survival rates of $<10 \%$ [2-4]. Currently is estimated that 7.820 men and 6.770 women will be diagnosed and 10.370 (men and women) will die of AML in 2013 in US. The majority of the AML cases are associated with nonrandom chromosomal translocations. Although over 700 recurrent aberrations have been described associated with the AML phenotype, the four more common are: $\mathrm{t}(15 ; 17)$ /PML-RAR, $\mathrm{t}(8 ; 21) /$ AML1-ETO. Inv(16)/core binding factor (CBF)b-MYH11, 11q23 and mixed lineage leukemia (MLL)-fusion proteins.

\footnotetext{
* Correspondence: sgutierr@udec.cl

'Departamento de Bioquimica y Biologia Molecular, Facultad de Ciencias Biologicas, Universidad de Concepcion, Casilla 160 C, 4089100, Concepcion, Chile

${ }^{2}$ Centro de Estudios Cientificos SINDAB, Santiago, Chile
}

Traditionally AML has been considered the result of genetic alterations leading to irreversible defects of critical gene functions such as proliferation, differentiation, apoptosis and gene transcription associated to leukemogenesis. The mutated genes are often grouped in two classes: genes which confer a growth advantage by activating downstream effectors of various signaling pathways (including members of the signal transducer and activator of transcription (STAT), PI3K and RAS-MAPK pathways) and genes which alter the expression of key transcriptional targets in myelopoiesis (e.g. PML, RUNX1, MLL). In all cases, the end result is that the affected cell loses the ability to differentiate and to respond to cell proliferation regulators. DNA in human cells is found associated to proteins forming the chromatin. Packing eukaryotic genomes into high-order chromatin structures is critical for controlling most, if not all, processes derived from DNA. The minimal repeating unit of chromatin is the nucleosome, comprised of 147 base pairs wrapped around a histone octamer core [5]. In comparison to "naked" DNA, nucleosomal DNA is less accessible for DNA-binding proteins such as transcription factors, DNA replication and DNA repair complexes. Nucleosome cores are connected by linker DNA sequences of variable length to give an average DNA length of approximately $200 \mathrm{bp}$. Arrays of $11-\mathrm{nm}$ nucleosomes are thought to condense into approximately 30-nm fibers. A fifth histone, the linker histone $\mathrm{H} 1$, is structurally distinct from other histones and it has been shown that facilitates compaction of nucleosomes into 30-nm fibers and higher order chromatin
C Biomed Central

(c) 2013 Gutierrez and Romero-Oliva; licensee BioMed Central Ltd. This is an Open Access article distributed under the terms of the Creative Commons Attribution License (http://creativecommons.org/licenses/by/2.0), which permits unrestricted use, distribution, and reproduction in any medium, provided the original work is properly cited. 
structures. Therefore, nucleosomes serve as a potent mechanism for controlling transcription and other processes that utilize DNA as template [6]. The changes between tightly packed DNA (heterochromatin) and exposed DNA (euchromatin) are coordinated through modifications of the nucleosome structure either by DNA methylation, histone post-translational modifications (e.g. acetylation, methylation) or by ATP-dependent chromatin remodeling complexes (a group of protein complexes that can slide nucleosomes on DNA or bring about the exchange or eviction of the histones). These heritable changes in DNA packing that regulate DNA transcriptional activity are collectively known as epigenetic modifications. In the past few years, several reports have linked the development of the AML phenotype to epigenetic alterations [7-9]. For instance, recent genome-wide and candidate-gene studies have identified somatic alterations in genes that encode proteins regulating DNA methylation and post-translational histone modifications. These data suggest that somatic alterations in epigenetic regulators are a common genetic event in AML and contribute to hematopoietic cell transformation. In fact, epigenetic changes play a crucial role in the regulation of gene expression and several studies have reported epigenetic abnormalities occurring within signaling pathways regulating proliferation, migration, growth, differentiation, transcription, and death signals that may be critical in the establishment and progression of malignancies [10]. This data are underscored by recent studies which suggest that mutations in a subset of epigenetic regulators, including TET2 (Ten eleven Translocation protein 2), ASXL1 (Additional Sex Combs protein 1) and DNA methyl transferase 3a (DNMT3a) [11-14], are associated with poor overall survival of AML patients; therefore, defining a new subset of high-risk leukemia that is in need of novel, mechanism-based therapies. More importantly, because the epigenetic modifications are reversible, therapies based in epigenetic modifiers hold the promise of being highly effective. In this review we will discuss recent data implicating epigenetic alterations in the pathogenesis of AML, risk stratification and therapeutic of patients with myeloid leukemia; patents applications presented worldwide related with epigenetic modifiers or modifications are also summarized.

\section{Epigenetics}

As mentioned above, epigenetics is defined as the study of heritable changes in gene expression that are not due to modifications in the DNA sequence. Epigenetic changes can be established through multiple molecular mechanisms that include DNA methylation, histone modifications and more recently, the action of small RNA that do not codify for a protein or polypeptide but can regulate gene expression, known as non-coding
RNAs (ncRNA). All of these different modifications are closely interrelated and can influence each other. Interestingly, epigenomic profiling studies of patients with AML have revealed alterations in DNA methylation $[15,16]$, oxidized derivatives of methylated cytosines [17], and alterations in histone post-translational modifications such as lysine methylation $[18,19]$, phosphorylation [20], and acetylation [21,22], suggesting a fundamental role for these modifitions in AML pathogenesis.

\section{DNA methylation}

In eukaryotes, ranging from plants to humans, DNA methylation is found exclusively at cytosine residues, which most commonly are forming part of a CpG dinucleotide. The $\mathrm{CpG}$ dinucleotides are not homogeneously distributed throughout the genome, normally they are clustered in short DNA regions highly rich in $\mathrm{CpG}$ that are known as $\mathrm{CpG}$ islands, and in highly repetitive regions such as centromers and retrotranposons $[23,24]$. Approximately $60 \%$ of the human genes have CpG islands in their regulatory regions (promoters) [25]. In the human genome there are about 13,000 CpG islands that are constitutively unmethylated [26]. However, a small but significant proportion of all $\mathrm{CpG}$ islands become methylated during development and when this happens the associated promoter is stably silent. Developmentally programmed CpG-island methylation of this kind is involved in genomic imprinting and $\mathrm{X}$ chromosome inactivation [23]. In contrast, most of the genomic CpG dinucleotides are methylated in all tissues and is thought to play a role in suppressing recognition of spurious intragenic DNA-binding sites to protect the cell from uncontrolled transcriptional activity and genomic instability [27].

DNA methylation results in stabilization of transcriptional repression and loss of gene function when present in promoters [23,28,29]; however, is associated with active expression when present into the genes (exons + introns) [30,31]. It has been suggested that these divergent relationships of DNA methylation with gene expression could be driven by a common role of DNA methylation in the stabilization of nucleosomes and in the occlusion of the transcriptional initiation site. Likewise, the introduction of a methyl group to the DNA can directly alter the binding of transcription factors $[23,32,33]$, further buffering against recognition of intragenic DNA-binding sites in actively expressed genes. Alternatively, DNA methylation may create new binding sites for proteins with methylation recognition domains which in turn induce gene repression by recruiting histone deacetylases (HDACs) [34,35].

DNA methylation occurs within $\mathrm{CpG}$ dinucleotides through addition of a methyl group at the $5^{\prime}$ position of the cytosine ring, forming 5-methyl cytosine, in a reaction catalyzed by enzymes known as DNA methyl 
transferases (DNMTs) [36]. There are three principal DNA methyltransferases: DNMT1, DNMT3a and DNMT3b. DNMT1 is the primary maintenance enzyme that preserves existing methylation patterns following DNA replication by adding methyl groups to corresponding daughter strands at the hemi-methylated CpG sites. DNMT3a and DNMT3b are methyltransferases that preferentially target unmethylated CpGs to initiate de novo methylation and therefore, they are highly expressed during embryogenesis but minimally expressed in adult tissues. A fourth family member, DNMT-3 L, lacks intrinsic methyltransferase activity; however it facilitates methylation of retrotransposons by interaction with DNMT3a and 3b [37].

DNA methylation is the most studied epigenetic alteration in cancer and was the first epigenetic alteration to be connected to its development [38,39]. CpG island methylation is now widely recognized to be associated with cancer-related changes in gene expression. These changes are produced mainly through three different mechanisms: hypomethylation, loss of imprinting, and hypermethylation. As mentioned above, in addition to regulation by DNA methylation itself, methylated DNA binding proteins (MBDs) can bind to methylated cytosine, and sequentially form a complex with histone deacetylase (HDAC) leading to chromatin compaction and gene silencing [40].

Global hypomethylation can lead to chromosomal instability, mutations and reactivation of various oncogenes. For instance, DNMT1 is responsible for the establishment of the DNA methylation pattern during DNA synthesis, and its deficiency in cells may lead to global hypomethylation. Another common alteration observed in cancer cells is DNA hypermethylation of promoter-associated $\mathrm{CpG}$ islands of tumor suppressor genes, which could serves as a surrogate for point mutations or deletions to cause transcriptional silencing of these genes [41,42].

A detailed study on the genomic methylation landscape of AML [43] have identified 16 distinct methylation patterns; each of these DNA-methylation AML subtypes displayed a unique epigenetic signature when compared with normal bone marrow CD34+ cells. These patterns most accurately overlapped with the currently known molecular subtypes of AML while simultaneously revealed the existence of additional epigenetic differences among patients. In fact, three of the 16 patients clusters correspond to AML subtypes defined by WHO: $t(8 ; 21), \operatorname{inv}(16)$ and $t(15 ; 17)$. Although this finding was perhaps expected, it is an important validation of the use of large-scale genome-wide DNA methylation profiling technology. Moreover, their data are consistent with the hypothesis that each of these fusion oncoproteins can drive the establishment of a specific epigenetic patterning in hematopoietic cells. Notably, this analysis also defined five new AML subtypes that could not be explained by any known morphologic, cytogenetic, or molecular feature. In fact, each of these AML subtypes displays an unique and significantly different epigenetic signature when compared to normal CD34+ control cells and a significant difference in patient survival was observed between these novel AML subtypes. Taken together, these results indicate that DNA methylation profiling identified clinically relevant AML subtypes that cannot be captured by any of the currently available diagnostic method.

Surprisingly, in this work the authors show that not all the identified methylated genes are repress at the expression level suggesting that other factor(s) may be still needed to silence them or alternatively that promoter methylation-mediated silencing is overcome by another mechanism [43].

The methylation profiles identified by Figueroa et al [43] support the idea that AML patients can be identified by a core set of genes that are commonly methylated in AML cells compared with normal hematopoietic cells. Moreover and more importantly, their results suggest that genomic methylation markers can be used for improved molecular classification and may have prognostic value for AML.

A novel class of point mutation described in AML affects the isocitrate dehydrogenase (IDH) genes [44-46]. The two enzymes affected (IDH1 and IDH2), normally catalyze the oxidative decarboxylation of isocitrate to $\alpha$-ketoglutarate and reduce NADP to NADPH. The point mutations cause loss of native enzymatic activities and confer novel enzymatic activity, catalyzing the conversion of $\alpha$-ketoglutarate to 2-hydroxyglutarate (2-HG), an oncometabolite. 2-HG is present at markedly elevated levels in the serum of patients with AML harboring IDH1 or IDH2 mutations, suggesting that 2-HG could be a biomarker for IDH-mutant AML [46]. All known mutations involve arginine (R), in codon 132 of IDH1 or codon 140 or 172 of IDH2. Although mutations of R140 in IDH2 exclusively result in the substitution of arginine to glutamine (IDH2-R140Q), mutations affecting IDH1-R132 or IDH2-R172 consist of a broader range of amino-acid substitutions (IDH1-R132H, IDH1-R132C, IDH2-R172K, IDH2-R172M and IDH2-R172S). IDH1 (R132) and IDH2 (R140) mutations are frequently accompanied by normal cytogenetics and nucleophosmin (NPM1) mutation, whereas IDH2(R172) is frequently the only mutation detected in AML. Moreover, mutational and methylation studies of a large cohort of AML patients demonstrate that IDH and TET2 mutations are mutually exclusive in AML and that patients with mutation in either IDH or TET2 genes exhibit similar methylation profiles characterized by global promoter hypermethylation [47]. Subsequent biochemical studies demonstrated that 2-HG inhibits TET family members, as $\alpha$ ketoglutarate 
is an essential cofactor of TET, and therefore its activity is reduced by the production of $2-\mathrm{HG}[48,49]$. TET proteins are dioxygenases that catalyze the conversion of 5 methyl cytosine $(5 \mathrm{mC})$ to 5 hydroxyl methyl cytosine $(5 \mathrm{hmC})$ [50]. Tet proteins can further oxidize $5 \mathrm{hmC}$ to generate 5-formylcytosine (5fC) and 5-carboxylcytosine $(5 \mathrm{caC})$, which can then be removed from the genome by thymine-DNA glycosylase (TDG) [51-53]. This suggests that $5 \mathrm{hmC}$ may act as a DNA demethylation intermediate. TET2 is often silenced or mutated in myelo proliferative disease (MPD), myelodysplastic syndrome (MDS), chronic myelomonocytic leukemia (CMML) and lymphomas suggesting a tumor suppressor role for TET2 in myeloid tumors, MPD and MDS. $5 \mathrm{hmC}$ not only impairs the binding of $5 \mathrm{mC}$ binding proteins [54], but has its own binding proteins [55] and shows unique distribution patterns in the genome [56,57], suggesting that $5 \mathrm{hmC}$ may serve as an epigenetic mark with different regulatory functions.

Mutations in TET2, IDH1 or IDH2 seem to have clinical relevance to risk stratification and/or therapeutic relevance in patients with AML. In fact, mutations in TET2 confer adverse overall survival in intermediate risk-subset of AML regardless of fms-related tyrosine kinase gene (FLT3) mutational status [58]. However, prognostic impact of IDH1/2 mutations seems to vary according to the specific mutation and also depends on the context of concurrent mutations of other genes. For instance, IDH2(R172) mutations confer a poor prognosis in AML patients, while IDH1(R132) mutation may predict poor outcome only in a subset of patients with molecular low-risk AML [59]. As mentioned above, the mutations in IDH generate a new enzymatic activity which result in 2-HG production affecting the enzymatic activity of the TET family; however, there are other $\alpha$ ketoglutarate-dependent enzymes that may also be inhibited by $2-\mathrm{HG}$ affecting the cell epigenetic state including members of the jumonji-domain-containing (JMJC) family of histone lysine demethylases, which demethylate lysines 9 and 36 of histone H3 (H3K9 and H3K36) [60].

More recently, two reports found that the (R)-enantiomer of 2-HG ((R)-2HG) may actually serve as a cofactor for the activation of the Egl-Nine (EGLN) family of prolyl hydroxylases (EGLN1-3) [61,62]. In both reports, the authors found that oncogenicity of IDH1 mutants in neural and hematopoietic cells may depend on the increased activity of the EGLN family, which normally mark the oxygen-labile subunit of the transcription factor hypoxiainducible factor (HIF) for proteasomal degradation. These data suggest that therapeutic targeting of the EGLN family may also be useful in the treatment of IDH-mutant AML.

\section{Histone modifications}

The major sites for histone posttranslational modifications are located in the $\mathrm{N}$-termini of the histone proteins, known as 'histone tails', which extend from the histone octamer of the nucleosome core (Figure 1). Histone may undergo several post-translational modifications, which can alter chromatin dynamics either by providing recognition sites for specific proteins (or protein complexes) or changing the nucleosome structure by altering electrostatic charge [63]. Histone modifications include acetylation, methylation, phosphorylation, sumoylation, ubiquitination, ribosylation and also proline isomerization. In most cases, the enzymes that carry out these functions are part of multiprotein complexes involved in some aspect of gene regulation or other genomic functions. According to the experimental evidence available, most of the histone tails modifications appear to have little effect in the internal structure of the nucleosome core [64]; however, they do affect interactions of nucleosomes with transcription factors and other nucleosomes. More recently, the characterization of bulkier histone modifications or modifications within internal histone domains has been suggested to potentially impact nucleosome structure [65]. Among the histone covalent modifications, the most studied are the acetylation in lysine (Figure 2) and the methylation in lysine and arginine residues (Figure 3) of histones $\mathrm{H} 3$ and $\mathrm{H} 4$, mainly in relation to their role in transcriptional regulation. In general, while histone acetylation is related to open chromatin structure, and therefore activation of gene transcription, histone methylation is found mostly associated with closed chromatin and transcriptional repression.

The enzymes that participate in establishing these histone modifications are the histone acetyltransferases (HAT) and the histone methyl tranferases (HMT) complexes, respectively; while the removal of the modifications are carried out by histone deacetylases (HDACs) and histone demethylases (HDMTs). Although the heritability of histone modifications themselves is not completely established, a great number of epigenetic cell memory proteins that have been implicated in human disease have also turned out to be enzymes that are involved in modify or recognize histone modifications [21,66-68].

\section{Histone acetylation}

In addition to their effect on histone-DNA interaction, individual histone modifications can enhance or decrease the presence of another modification on a target gene, they can also interact with signaling pathways and with other epigenetic regulators such as DNA methylation, and noncoding RNAs (ncRNAs). This experimental evidence has led to the proposal of a histone code, which would be read by specific proteins or proteins complexes for the epigenetic regulation of gene expression [69,70]. Central to the establishment of the histone code, is the activity of HAT and HDAC enzymes. In fact, some HATs are recurrent components of 


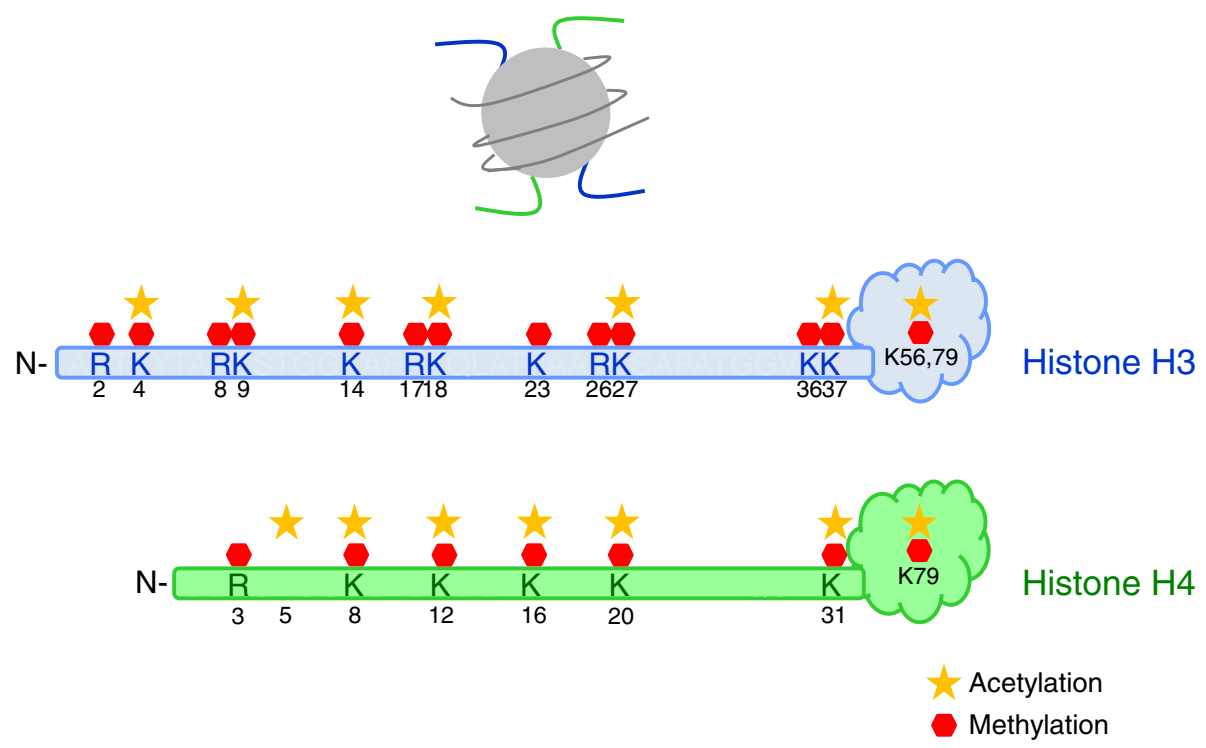

Figure 1 Histone post-translational modifications. Top panel correspond to a diagrammatic representation of a nucleosome showing histone $\mathrm{H} 3$ and $\mathrm{H} 4 \mathrm{~N}$-terminus (histone tails), which extend from the nucleosome particle. Bottom panel show some of the specific amino-acid residues that are methylated and/or acetylated in the N-terminus of histone $\mathrm{H} 3$ and $\mathrm{H} 4$ as well as some of the residues modified in the histones globular domain.

fusion oncoproteins generated by chromosomal rearrangement in leukemia, for example $\mathrm{t}(8 ; 16)(\mathrm{p} 11, \mathrm{p} 13)$ associated with AML generate the fusion protein MOZCBP which is composed for two HAT enzymes: MOZ (MOnocytic leukemia Zinc-finger protein) and CBP (CREBBinding Protein). The different fusion proteins contribute to leukemic transformation most likely by a mechanism involving mistargeted histone acetylation and thus aberrant activation of gene expression [71,72]. Moreover, in a recent study, inactivating mutations within the HAT domain of CBP have been found in approximately $18 \%$ of relapsed AML cases, suggesting that the impaired HAT activity could be linked to resistant to therapy in AML [22].

It has also been proposed that aberrant recruitment of HDACs to target genes owing to oligomerization of a

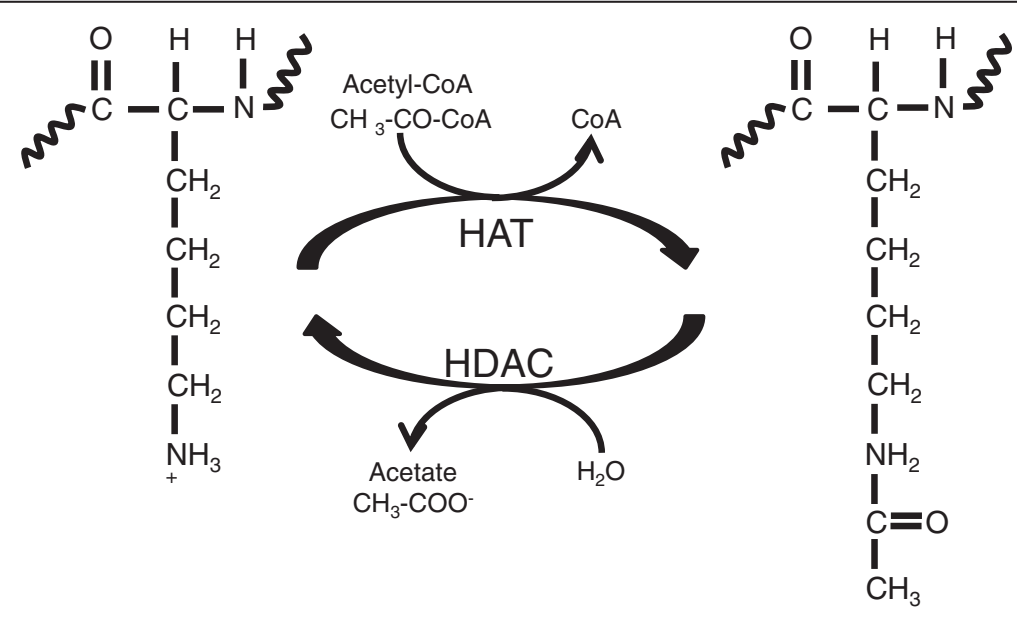

Lysine

Acetyl-lysine

Figure 2 Histone acetylation. Histone acetyltransferase complexes (HATs) catalyze the transfer of an acetyl group from acetylCoA to the $\varepsilon$-amino of a lysine residue. Removal of an acetyl group from a $\varepsilon$-N-acetyl lysine amino acid on a histone protein is carried out by the histone deacetylase complexes (HDACs). Curly lines represent the rest of the protein molecule. 


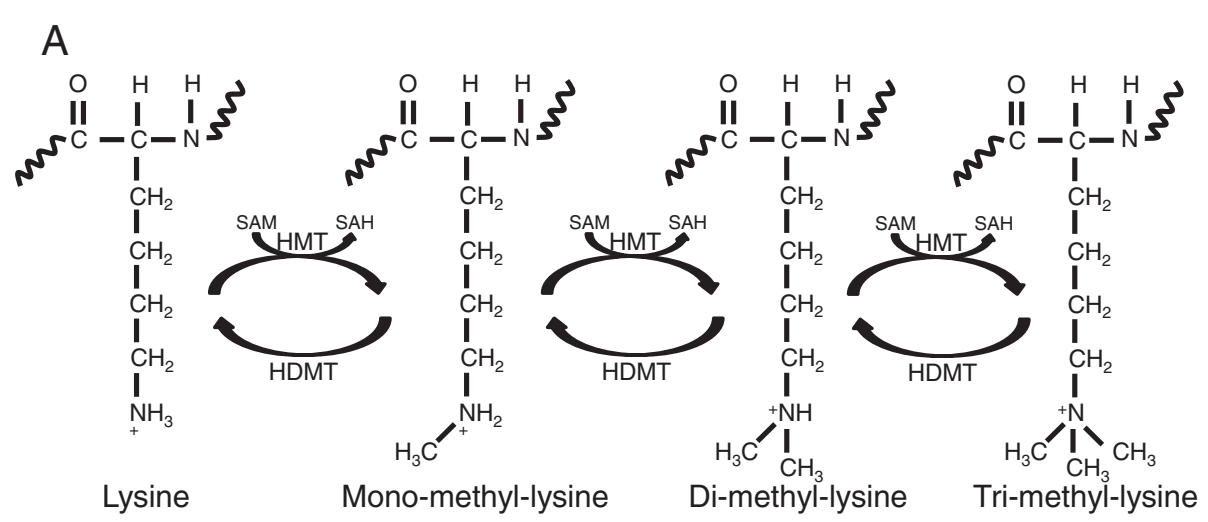

B

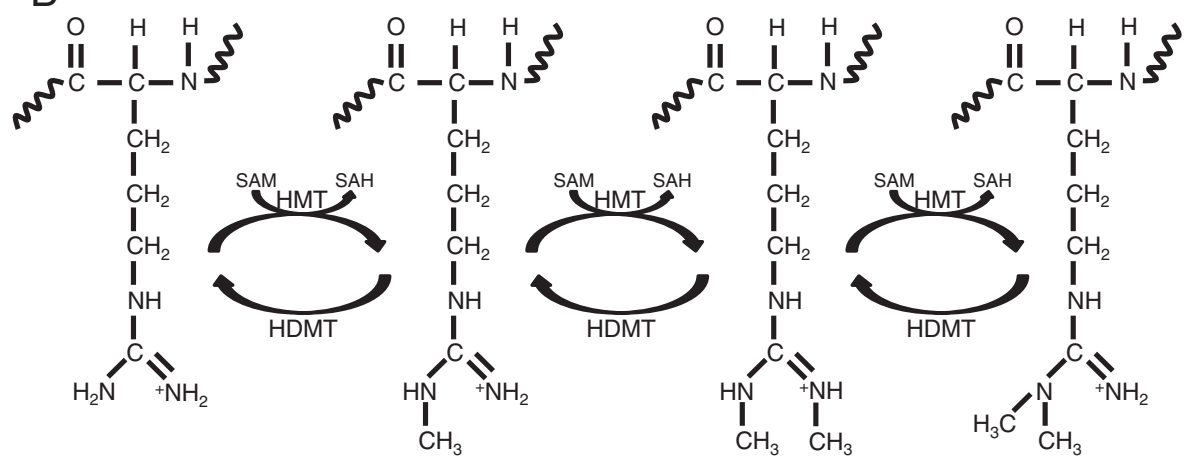

$\begin{array}{lll}\text { Arginine } \quad \text { Mono-methyl-arginine } & \begin{array}{l}\text { Symmetrical di- } \\ \text { methyl-arginine }\end{array} & \begin{array}{c}\text { Asymmetrical di- } \\ \text { methyl-arginine }\end{array}\end{array}$

Figure 3 Histones can only be methylated on lysine (K) and arginine (R) residues. A) Lysine is able to be mono-, di-, or trimethylated with a methyl group replacing each hydrogen of its $\mathrm{NH} 3+$ group. B) Arginine, with a free $\mathrm{NH} 2$ and $\mathrm{NH} 2+$ groups, is able to be mono- or dimethylated. Arginine methylation can be asymmetric on the NH2 group or symmetric with one methyl on each group. Specific histone methyl transferases (HMT) and histone demethylases (HDM) catalyze these processes. Curly lines represent the rest of the protein molecule.

chimeric transcription factor could be a mechanism underlying a broader group of AMLs. Indeed, the AML1-ETO fusion protein was demonstrated to act through an aberrant HDAC-recruiting mechanism that leads to the block of hematopoietic differentiation [73]. Altered distribution of HDAC1 in AML and consequent specific pattern of chromatin modifications at hematopoietic genes could also be associated with the patient's outcome, and thus be a tool to improve prognosis prediction [74]. Interestingly, the implications of HDACs in leukemia is not limited to their aberrant recruitment by fusion proteins [75-77], as alterations in the expression of various HDAC isoforms have also been associated with the patient's prognosis [78].

\section{Histone methylation}

MLL (Mixed Lineage Leukemia protein) is a histone methyltransferase required for the epigenetic maintenance of gene activation during development [79-81] and is also mutated in a subset of aggressive acute leukemias (both ALL and AML) [82]. MLL maintains gene activation in part by methylating histone 3 on lysine 4 $[83,84]$. The most common leukemogenic MLL mutations are chromosome translocations that fuse the $\mathrm{N}$-terminus of the MLL gene in-frame with any of more than 70 different partner genes producing novel MLL fusion proteins $[85,86]$. Interestingly, the leukemias caused by MLL fusion proteins have very few additional genetic mutations [87-90], suggesting that the formation of the fusion protein alone is sufficient for initiating leukemogenesis. The $\mathrm{N}$-terminus involved in formation of MLL fusion proteins retains the MLL histone methyltransferase activity and therefore it seems that the leukemia-causing molecular mechanism is the aberrant target of epigenetic modifications. Among the genes misregulated by MLL fusion proteins, the most relevant class is the HOXA family, a group of genes fundamental in development, which are normally regulated by MLL and are frequently overexpressed in leukemia [91]. Recently, Nguyen et al [92] have demonstrated that MLL-AF9 fusion protein interact with DOT1L, an H3K79 methyltransferase and this interaction 
is required for both initiation and maintenance of MLLAF9-induced leukemogenesis both in vitro and in vivo. Moreover, through gene expression and chromatin immunoprecipitation analysis the authors demonstrated that mistargeting of DOT1L, result in epigenetic changes at HOXA genes. In fact, according to their results H3K79 methylation and the consequent up-regulation of HOXA genes underlie the molecular mechanism of how DOT1L contributes to MLL-AF9-mediated leukemogenesis. DOT1L also has been associated to the leukemic transformation by MLL-AF10, MLL-ENL and CALM-AF10, presumably through the same mechanism $[90,93,94]$.

Although the involvement of histone demethylases (HDMs) in cancer progression has already been established, there is no much data regarding their role in leukemia. Recently it was found that lysine (K)-specific demethylase 2B (KDM2b), a demethylase specific for H3K36me2, is upregulated in AML and has a critical role both in the initiation and progression of the disease [95].

\section{AML treatment with epigenetics drugs}

There are more than 100 epigenetic agents currently under investigation and a few have received US Food and Drug Administration (FDA) approval in the last decade. According to the web site ClinicalTrials.gov, maintained by the US National Institute of Health and that currently lists 143,954 studies with locations in all 50 states and in 184 countries, there are 1.818 studies for AML. From the total number of studies, 608 are open studies defined by clinical trial web site as: "studies that are currently recruiting participants, will be recruiting participants in the future, or involve drugs that are available for expanded access". A search for AML and epigenetic retrieved 12 open studies, however searching for DNA methylation and AML or histone and AML retrieved 24 and 48 studies, respectively.

\section{Clinical drugs targeting DNA methylation}

DNA methyltransferase inhibitors have found the earliest and greatest success as prototypical epigenetic agents. In 2004, the DNA methyltransferase inhibitor, azacytidine (VidazaTM), was approved by the FDA for the treatment of myelodysplastic syndrome MDS, on the basis of phase II and III clinical trials. In 2006 a second DNA methyltransferase inhibitor, decitabine (dacogene) received FDA approval also for treatment of MDS. In these studies, treatment with decitabine or azacitidine exhibit a response rate up to $30 \%$ that was relatively durable when compared to placebo $[96,97]$. Azacitidine is now also being evaluated in clinical trials on other malignant diseases such as nonsmall cell lung cancer and pancreatic cancer $[98,99]$.

Azacitidine and decitabine (5-aza-2 deoxycytidine) are cytidine analogs in which the carbon atom at position 5 in the pyrimidine ring has been replaced by a nitrogen atom.
Following cellular uptake, azacitidine and decitabine are converted into their corresponding monophosphates, diphosphates, and triphosphates nucleotides. As nucleotide analogues, they replace cytosine during DNA replication, producing DNA demethylation by inactivation of DNMTs. Despite indiscriminately targeting DNMTs [100], they were found at low dosages to selectively reactivate gene expression with relatively few side effects [101]. Incorporation into the DNA results in the formation of adducts between the DNA and DNMT. Although at high doses, the DNA is not able to recover and cell death occurs, at lower doses the formed adducts are degraded by the proteosome, after which the DNA is restored. DNA synthesis is then resumed in the absence of DNMT, and as a consequence the aberrant DNA methylation pattern can no longer be established in the DNA daughter strands. In this manner, a low dose of azacitidine or decitabine is able to induce re-expression of previously silenced genes [102-104].

\section{Clinical drugs targeting histone modifications}

Several clinical trials of histone deacetylase inhibitors (HDACi) have been conducted in solid and hematological malignancies. Interestingly, until now the results demonstrate a preferential efficacy in hematological malignancies [105]. These compounds are also beginning to be tested in combination therapies, either as chemo sensitizing agents in association with standard chemotherapy drugs or in combination with DNA methyl transferase inhibitors (Table 1). In human, the biological target of HDACi, the histone deacetylases complexes (HDACs), comprise a family of 18 genes sub-divided into 4 classes based on their sequence homology to yeast proteins, sub-cellular localization and enzymatic activities [106]. HDAC belonging to class I (HDAC1, HDAC2, HDAC3 and HDAC8), class IIa (HDAC4, HDAC5, HDAC7 and HDAC9), class IIb (HDAC6 and HDAC10) and class IV (HDAC11) exhibit a Zn dependent enzymatic activity, which is the bases of their interaction with the HDACi currently used. Class III (or Sirtuins) constitute a structurally separate subfamily which exhibit a NAD-dependent enzymatic activity.

HDACi can be classified based on their general chemical structure in short fatty acid, cyclic peptide benzamide and hydroxamic acids (Table 1). These inhibitors differ in potency, pharmacokinetic properties and, more importantly, on their selectivity to inhibition targets. According to their in vitro selectivity profile, HDACi are classified in pan HDACi, which inhibit HDAC class I and II (e.g. vorinostat, panobinostat and belinostat), or selective $\mathrm{HDACi}$, which inhibit either HDAC class I (e.g. mocetinostat, entinostat) or class II (e.g. MC1568) [107]. It is generally accepted that particular attention should be paid to HDACi inhibition selectivity in the interpretation of experimental results; although it must be stress that the selectivity 
Table 1 Selected histone deacetylase inhibitors

\begin{tabular}{|c|c|c|c|c|c|}
\hline \multirow[t]{2}{*}{ Name } & \multirow[t]{2}{*}{ Chemical class } & \multirow[t]{2}{*}{ Formula } & \multirow[t]{2}{*}{ Target } & \multicolumn{2}{|c|}{ Number AML trials } \\
\hline & & & & $\begin{array}{l}\text { Open/ } \\
\text { Total }\end{array}$ & $\begin{array}{c}\text { + Azacytidine } \\
\text { open/Total }\end{array}$ \\
\hline Phenylbutyrate & $\begin{array}{l}\text { Short fatty acid } \\
\text { chain }\end{array}$ & & Pan-inhibitor & $0 / 6$ & 0 \\
\hline Valproic acid & $\begin{array}{l}\text { Short fatty acid } \\
\text { chain }\end{array}$ & & Classi/Ila & $5 / 14$ & $1 / 7$ \\
\hline Vorinostat (SAHA) & Hydroxamic acid & & Pan-inhibitor & $8 / 25$ & $2 / 4$ \\
\hline
\end{tabular}

Belinostat (PXD101) Hydroxamic acid

Panobinostat (LBH589)

Hydroxamic acid<smiles>Cc1[nH]c2ccccc2c1CCNCc1ccc(/C=C/C(=O)NO)cc1</smiles><smiles>O=C(/C=C/c1cccc(S(=O)(=O)Nc2ccccc2)c1)NO</smiles>

Pan-inhibitor $\quad 1 / 4$

$0 / 1$

Pan-inhibitor $\quad 7 / 11$

$2 / 3$<smiles>CC(/C=C/C(=O)NO)=C\[C@@H](C)C(=O)c1ccc(N(C)C)cc1</smiles>

Pan-inhibitor 0

0 
Gutierrez and Romero-Oliva Journal of Hematology \& Oncology 2013, 6:57

Page 9 of 14

http://www.jhoonline.org/content/6/1/57

Table 1 Selected histone deacetylase inhibitors (Continued)

Givinostat (ITF2375)

Mocetinostat

(MGCD0103)
Hydroxamic acid

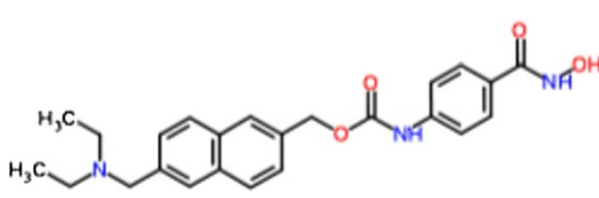

Benzamide

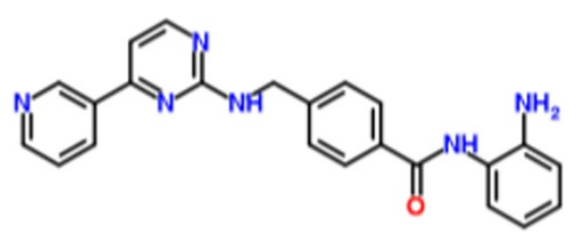

Class I/IV

$0 / 3$

0/1

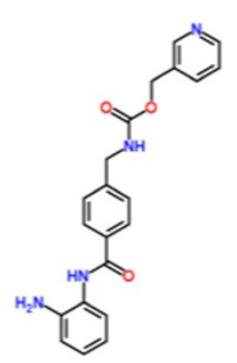

Class I

$2 / 7$

$1 / 3$

(MS275-SNDX275)

Romidepsin

(Depsipeptide)

Cyclic tetrapeptide

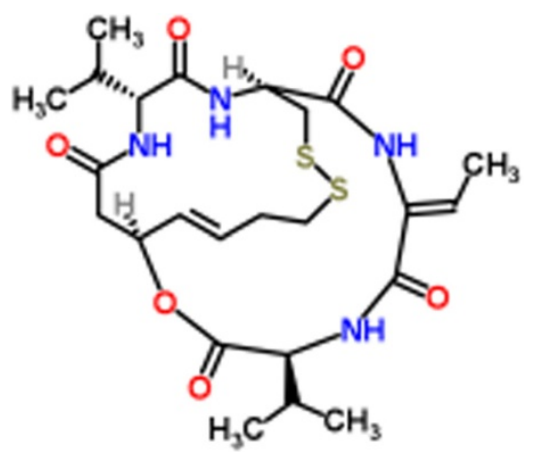

Class I

$0 / 5$

0/1

Trapoxin B

Cyclic tetrapeptide

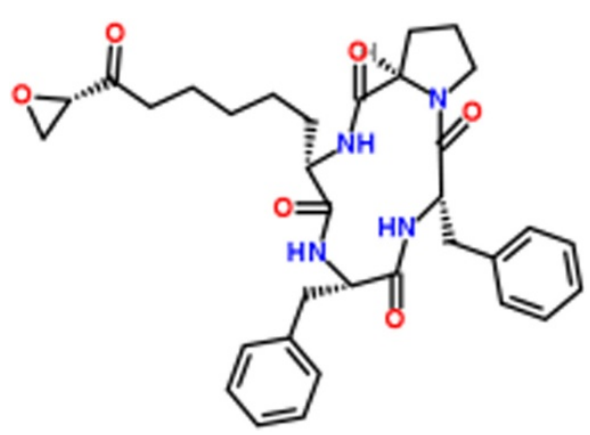

Class I/Ila

0

0

Chemical structures from http://www.chemspider.com. 
profile has been mainly determined in vitro and therefore may not reflect the physiological state of HDACs. Moreover, it is still unknown if a selective HDACi could have a better balance among desired and undesired effect than a pan HDACi.

The effects of HDAC inhibitors appear to be to promote G1 or G2/M cell-cycle arrest, as well as apoptosis and cell differentiation. It is important to keep in mind that histone are not the only targets of HDAC, but among their know substrates are also included p53, signal transducer and activator of transcription 3 (STAT3), heat shock protein 90 (hsp 90), and other important proteins and therefore changes in the acetylation status of these other proteins may contribute to the biological effects observed [108].

Only two HDACi have been approved by the FDA: Vorinostat for the treatment of cutaneous T cell lymphoma (CTCL) on October 6, 2006, which has also given encouraging results in a phase II trial for MDS in combination with Idarubicin and Cytarabine, and Romidepsin for CTCL on November 5, 2009. However, there are several more been tested in phase I, II or III for different diseases. Currently, according to Clinical Trials Database (www. clinicaltrials.gov), for AML treatment there are ongoing clinical trials for: valproic acid, vorinostat, belinostat, panobinostat and etinostat either alone or in combination with the DNA methylation inhibitor 5-azacytidine (decitabine) (Table 1).

Somehow unexpectedly, HAT inhibitors have also been shown to have some antitumor activity. This contrasts with the global hypoacetylation already seen in many cancers. Naturally occurring drugs such as curcumin, garcinol, and anacardic acid appear to selectively inhibit the acetyl transferases p300, CBP, or PCAF, leading to apoptosis or sensitization to therapies such as radiation [109-111]. Until know no clinical trials have yet been completed with this class of agents.

Epigenetic based therapies have so far focused on the use of DNMTs and HDACs inhibitors, which tend to have more general and widespread effects on gene regulation in the cell. However, if a unique molecular pathway can be identified in diseases caused by epigenetic mechanisms, they will be excellent candidates for the development of more targeted therapies that focus on specific gene targets, individual binding domains, or specific enzymatic activities. Therefore, designing effective targeted therapies depends on a clear understanding of the role of epigenetic mutations during disease progression.

AML Epigenetics: patent applications and granted patents In this section we summarize, current information publically available in the international system of Patents of Inventions registered mainly at the World Intellectual Property Office (WIPO, http://www.wipo.int/portal/index. html.en) as well as at the european (http://worldwide. espacenet.com), the japanese (http://www.jpo.go.jp/) and the US (http://patft.uspto.gov/) patents offices. Briefly, patents applications are those still in analysis to define if they will be or not granted, but we include them as a sample of the efforts to develop new technological strategies against AML and its epigenetics causes. Tables 2 and 3 summarize patent documents related to the epigenetic tools currently proposed for AML diagnostic and therapeutic strategies.

\section{Conclusions}

Despite recent major advances in our understanding of the genetics of myeloid malignancies, there have been far fewer examples of how these insights have been translated to novel therapies. Epigenetic modifiers provide new targets for therapeutic intervention. Mutations in IDH1 and IDH2 that result in a new enzymatic activity may represent novel, tractable targets for this genetically defined subset of leukemia patients. Likewise, enzymatic activities associated with genes involved in leukemic transformation (including H3K79 methyltransferase activity, histone acetyltransferase activity and other chromatin enzymatic functions) have just recently been explored from a therapeutic standpoint. Worldwide scientific and patents of inventions literature, suggest that advances in our knowledge of the genetics of myeloid malignancies, coupled with an improved understanding of the role of specific

Table 2 Selected strategies using epigenetic tools for leukemia diagnostic as proposed in the International Database for Patents of Inventions

\begin{tabular}{|c|c|c|}
\hline Patent document & Target gene & Method based on \\
\hline WO2006060429 & HDAC1 gene & $\begin{array}{l}\text { Detection of five point mutations in HDAC1: M51L, Q111K, T114A, V157G } \\
\text { and a premature stop codon at R34 }\end{array}$ \\
\hline WO2012078288 & DNMT3A & Detection of one or more mutations, mainly at Arg-882 \\
\hline WO2009150229 & TET2 & Detection of expression levels or mutations in this putative suppressor gene \\
\hline US2009317801 & $\begin{array}{l}\text { Genes located on the long arm } \\
\text { of chromosome } 17 \text { (17q25.3) }\end{array}$ & Analysis of methylation state of a target gene in this chromosomal region \\
\hline US2011281270 & CEBPA & Detection of bi allelic mutations in CCAAT-enhancer binding protein gene \\
\hline
\end{tabular}


Table 3 Selected compounds proposed as epigenetic tools for leukemia treatment according to the International Database for Patents of Inventions

Patent document

WO2010009285

US20080138329

US2010305059

US2006106049

ES2399670<smiles>CNC(=O)/C=C/c1ccc(CNCCc2c(C)[nH]c3ccccc23)cc1</smiles>

HDAC inhibitor

DNMT inhibitor

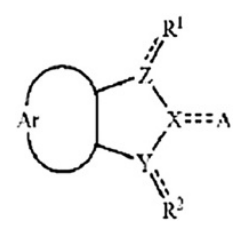

antiproliferative<smiles>[Y]c1cc(Cl)ccc1OC</smiles>

HDAC inhibitor

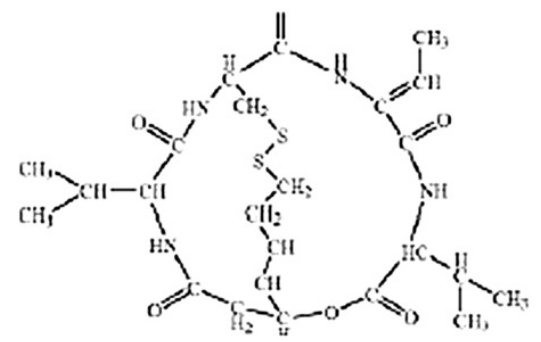<smiles>CN1CC(CNCC2CCN(c3ncc(C(=O)NO)cn3)CC2)c2ccccc21</smiles>

epigenetic modifications in leukemogenesis, may probably lead to an increased number and/or progress in the development of therapies that improve outcomes for patients with MPN, MDS and AML in future years. Moreover, there is hope that this knowledge could also give rise to new diagnostic and/ or prognostic methods allowing the design of a personalized treatment for each patient, as well as more sensitive procedures to detect the pathologies sooner, which is particularly relevant considering that some of the most common cancer types are largely curable if they are detected early and treated appropriately. 


\section{Competing interests}

The authors declare that they have no competing interests.

\section{Authors' contributions}

FRO and SEG have contributed to data preparation, drafting and revising the manuscript. Both authors read and approved the final manuscript.

\section{Acknowledgements}

This work has been supported by Fondo Nacional de Desarrollo Cientifico y Tecnologico (FONDECYT) Grant 1130697 awarded to SEG.

Received: 4 June 2013 Accepted: 5 August 2013

Published: 13 August 2013

\section{References}

1. Swerdlow SH, Campo E, Harris NL, Jaffe ES, Pileri SA, Stein H, Thiele J, Vardiman JW: WHO Classification of Tumours of Haematopoietic and Lymphoid Tissues. 4th edition. Lyon: IARC; 2008.

2. Wahlin $\mathrm{A}$, Hornsten $\mathrm{P}$, Jonsson $\mathrm{H}$ : Remission rate and survival in acute myeloid leukemia: impact of selection and chemotherapy. Eur J Haematol 1991, 46(4):240-247.

3. Lowenberg B, Ossenkoppele GJ, Van Putten W, Schouten HC, Graux C, Ferrant A, Sonneveld P, Maertens J, Jongen-Lavrencic M, Von Lilienfeld-Toal $M$, et al: High-dose daunorubicin in older patients with acute myeloid leukemia. N Engl J Med 2009, 361(13):1235-1248.

4. Kantarjian H, O'Brien S, Cortes J, Giles F, Faderl S, Jabbour E, Garcia-Manero G, Wierda W, Pierce S, Shan J, et al: Results of intensive chemotherapy in 998 patients age 65 years or older with acute myeloid leukemia or highrisk myelodysplastic syndrome: predictive prognostic models for outcome. Cancer 2006, 106(5):1090-1098.

5. Richmond TJ, Davey CA: The structure of DNA in the nucleosome core. Nature 2003, 423(6936):145-150.

6. Li B, Carey M, Workman JL: The role of chromatin during transcription. Cell 2007, 128(4):707-719.

7. Galm O, Herman JG, Baylin SB: The fundamental role of epigenetics in hematopoietic malignancies. Blood Rev 2006, 20(1):1-13.

8. Chen J, Odenike O, Rowley JD: Leukaemogenesis: more than mutant genes. Nat Rev Cancer 2010, 10(1):23-36.

9. Barrero MJ, Berdasco M, Paramonov I, Bilic J, Vitaloni M, Esteller M, Izpisua Belmonte JC: DNA hypermethylation in somatic cells correlates with higher reprogramming efficiency. Stem cells 2012, 30(8):1696-1702.

10. Berdasco M, Esteller M: Aberrant epigenetic landscape in cancer: how cellular identity goes awry. Developmental cell 2010, 19(5):698-711.

11. Delhommeau F, Dupont S, Della Valle V, James C, Trannoy S, Masse A, Kosmider O, Le Couedic JP, Robert F, Alberdi A, et al: Mutation in TET2 in myeloid cancers. N Engl J Med 2009, 360(22):2289-2301.

12. Abdel-Wahab O, Pardanani A, Patel J, Wadleigh M, Lasho T, Heguy A, Beran M, Gilliland DG, Levine RL, Tefferi A: Concomitant analysis of EZH2 and ASXL1 mutations in myelofibrosis, chronic myelomonocytic leukemia and blast-phase myeloproliferative neoplasms. Leukemia 2011, 25 (7):1200-1202

13. Abdel-Wahab O, Pardanani A, Rampal R, Lasho TL, Levine RL, Tefferi A: DNMT3A mutational analysis in primary myelofibrosis, chronic myelomonocytic leukemia and advanced phases of myeloproliferative neoplasms. Leukemia 2011, 25(7):1219-1220.

14. Ley TJ, Ding L, Walter MJ, McLellan MD, Lamprecht T, Larson DE, Kandoth C, Payton JE, Baty J, Welch J, et al: DNMT3A mutations in acute myeloid leukemia. N Engl J Med 2010, 363(25):2424-2433.

15. Figueroa ME, Skrabanek L, Li Y, Jiemjit A, Fandy TE, Paietta E, Fernandez H, Tallman MS, Greally JM, Carraway $H$, et al: MDS and secondary AML display unique patterns and abundance of aberrant DNA methylation. Blood 2009, 114(16):3448-3458.

16. Jiang Y, Dunbar A, Gondek LP, Mohan S, Rataul M, O'Keefe C, Sekeres M, Saunthararajah Y, Maciejewski JP: Aberrant DNA methylation is a dominant mechanism in MDS progression to AML. Blood 2009, 113(6):1315-1325.

17. Ko M, Huang Y, Jankowska AM, Pape UJ, Tahiliani M, Bandukwala HS, An J, Lamperti ED, Koh KP, Ganetzky R, et al: Impaired hydroxylation of 5-methylcytosine in myeloid cancers with mutant TET2. Nature 2010, 468(7325):839-843.
18. Abdel-Wahab O, Adli M, LaFave LM, Gao J, Hricik T, Shih AH, Pandey S, Patel JP, Chung YR, Koche R, et al: ASXL1 mutations promote myeloid transformation through loss of PRC2-mediated gene repression. Cancer cell 2012, 22(2):180-193.

19. Morin RD, Johnson NA, Severson TM, Mungall AJ, An J, Goya R, Paul JE, Boyle M, Woolcock BW, Kuchenbauer F, et al: Somatic mutations altering EZH2 (Tyr641) in follicular and diffuse large B-cell lymphomas of germinal-center origin. Nature genetics 2010, 42(2):181-185.

20. Dawson MA, Bannister AJ, Gottgens B, Foster SD, Bartke T, Green AR, Kouzarides T: JAK2 phosphorylates histone H3Y41 and excludes HP1alpha from chromatin. Nature 2009, 461(7265):819-822.

21. Pasqualucci L, Dominguez-Sola D, Chiarenza A, Fabbri G, Grunn A, Trifonov V, Kasper LH, Lerach S, Tang H, Ma J, et al: Inactivating mutations of acetyltransferase genes in B-cell lymphoma. Nature 2011, 471(7337):189-195.

22. Mullighan CG, Zhang J, Kasper LH, Lerach S, Payne-Turner D, Phillips LA, Heatley SL, Holmfeldt L, Collins-Underwood JR, Ma J, et al: CREBBP mutations in relapsed acute lymphoblastic leukaemia. Nature 2011, 471(7337):235-239.

23. Bird A: DNA methylation patterns and epigenetic memory. Genes deve 2002, 16(1):6-21.

24. Smith ZD, Meissner A: DNA methylation: roles in mammalian development. Nat Rev Genet 2013, 14(3):204-220.

25. Wang $Y$, Leung FC: An evaluation of new criteria for $\mathrm{CpG}$ islands in the human genome as gene markers. Bioinformatics 2004, 20(7):1170-1177.

26. Straussman R, Nejman D, Roberts D, Steinfeld I, Blum B, Benvenisty N, Simon I, Yakhini Z, Cedar H: Developmental programming of CpG island methylation profiles in the human genome. Nat Struct Biol 2009, 16(5):564-571.

27. Suzuki MM, Bird A: DNA methylation landscapes: provocative insights from epigenomics. Nat Rev Genet 2008, 9(6):465-476.

28. Pai AA, Bell JT, Marioni JC, Pritchard JK, Gilad Y: A genome-wide study of DNA methylation patterns and gene expression levels in multiple human and chimpanzee tissues. PLoS genetics 2011, 7(2):e1001316.

29. Zeng J, Konopka G, Hunt BG, Preuss TM, Geschwind D, Yi SV: Divergent whole-genome methylation maps of human and chimpanzee brains reveal epigenetic basis of human regulatory evolution. Am J Hum Genet 2012, 91(3):455-465.

30. Zemach A, McDaniel IE, Silva P, Zilberman D: Genome-wide evolutionary analysis of eukaryotic DNA methylation. Science 2010, 328(5980):916-919.

31. Jjingo D, Conley AB, Yi SV, Lunyak W, Jordan IK: On the presence and role of human gene-body DNA methylation. Oncotarget 2012, 3(4):462-474.

32. Shukla S, Kavak E, Gregory M, Imashimizu M, Shutinoski B, Kashlev M, Oberdoerffer P, Sandberg R, Oberdoerffer S: CTCF-promoted RNA polymerase II pausing links DNA methylation to splicing. Nature 2011, 479(7371):74-79.

33. Wang HT, Weng MW, Chen WC, Yobin M, Pan J, Chung FL, Wu XR, Rom W, Tang MS: Effect of CpG methylation at different sequence context on acrolein- and BPDE-DNA binding and mutagenesis. Carcinogenesis 2013, 34(1):220-227.

34. Jones PL, Veenstra GJ, Wade PA, Vermaak D, Kass SU, Landsberger N, Strouboulis J, Wolffe AP: Methylated DNA and MeCP2 recruit histone deacetylase to repress transcription. Nature genetics 1998, 19(2):187-191.

35. Nan $\mathrm{X}, \mathrm{Ng} \mathrm{HH}$, Johnson CA, Laherty CD, Turner BM, Eisenman RN, Bird A: Transcriptional repression by the methyl-CpG-binding protein $\mathrm{MeCP} 2$ involves a histone deacetylase complex. Nature 1998, 393(6683):386-389.

36. Issa JP, Kantarjian HM: Targeting DNA methylation. Clin Cancer Res 2009 15(12):3938-3946.

37. Denis $\mathrm{H}$, Ndlovu MN, Fuks F: Regulation of mammalian DNA methyltransferases: a route to new mechanisms. EMBO reports 2011, 12(7):647-656.

38. Lewandowska J, Bartoszek A: DNA methylation in cancer development, diagnosis and therapy-multiple opportunities for genotoxic agents to act as methylome disruptors or remediators. Mutagenesis 2011, 26(4):475-487

39. Wu SC, Zhang Y: Active DNA demethylation: many roads lead to Rome. Nat Rev Mol Cell Biol 2010, 11(9):607-620.

40. Duthie SJ: Epigenetic modifications and human pathologies: cancer and CVD. Proc Nutr Soc 2011, 70(1):47-56.

41. Jones PA: DNA methylation and cancer. Oncogene 2002, 21(35):5358-5360.

42. Colacino JA, Arthur AE, Dolinoy DC, Sartor MA, Duffy SA, Chepeha DB, Bradford CR, Walline HM, McHugh JB, D'Silva N, et al: Pretreatment dietary 
intake is associated with tumor suppressor DNA methylation in head and neck squamous cell carcinomas. Epigenetics 2012, 7(8):883-891.

43. Figueroa ME, Lugthart S, Li Y, Erpelinck-Verschueren C, Deng X, Christos PJ, Schifano E, Booth J, Van Putten W, Skrabanek L, et al: DNA methylation signatures identify biologically distinct subtypes in acute myeloid leukemia. Cancer cell 2010, 17(1):13-27.

44. Mardis ER, Ding L, Dooling DJ, Larson DE, McLellan MD, Chen K, Koboldt $D C$, Fulton RS, Delehaunty KD, McGrath SD, et al: Recurring mutations found by sequencing an acute myeloid leukemia genome. $N$ Engl J Med 2009, 361(11):1058-1066

45. Marcucci G, Maharry K, Wu YZ, Radmacher MD, Mrozek K, Margeson D, Holland KB, Whitman SP, Becker H, Schwind S, et al: IDH1 and IDH2 gene mutations identify novel molecular subsets within de novo cytogenetically normal acute myeloid leukemia: a Cancer and Leukemia Group B study. Asia Pac J Clin Oncol 2010, 28(14):2348-2355.

46. Ward PS, Patel J, Wise DR, Abdel-Wahab O, Bennett BD, Coller HA, Cross JR, Fantin VR, Hedvat CV, Perl AE, et al: The common feature of leukemiaassociated IDH1 and IDH2 mutations is a neomorphic enzyme activity converting alpha-ketoglutarate to 2-hydroxyglutarate. Cancer cell 2010, 17(3):225-234

47. Akalin A, Garrett-Bakelman FE, Kormaksson M, Busuttil J, Zhang L, Khrebtukova I, Milne TA, Huang Y, Biswas D, Hess JL, et al: Base-pair resolution DNA methylation sequencing reveals profoundly divergent epigenetic landscapes in acute myeloid leukemia. PLoS genetics 2012, 8 (6):e1002781.

48. Xu W, Yang H, Liu Y, Yang Y, Wang P, Kim SH, Ito S, Yang C, Wang P, Xiao MT, et al: Oncometabolite 2-hydroxyglutarate is a competitive inhibitor of alpha-ketoglutarate-dependent dioxygenases. Cancer cell 2011, 19(1):17-30

49. Figueroa ME, Abdel-Wahab O, Lu C, Ward PS, Patel J, Shih A, Li Y, Bhagwat $\mathrm{N}$, Vasanthakumar A, Fernandez HF, et al: Leukemic IDH1 and IDH2 mutations result in a hypermethylation phenotype, disrupt TET2 function, and impair hematopoietic differentiation. Cancer cell 2010, 18(6):553-567.

50. Tahiliani M, Koh KP, Shen Y, Pastor WA, Bandukwala H, Brudno Y, Agarwal S, lyer LM, Liu DR, Aravind L, et al: Conversion of 5-methylcytosine to 5-hydroxymethylcytosine in mammalian DNA by MLL partner TET1. Science 2009, 324(5929):930-935.

51. He Y-F, Li B-Z, Li Z, Liu P, Wang Y, Tang Q, Ding J, Jia Y, Chen Z, Li L, et al: Tet-Mediated Formation of 5-Carboxylcytosine and Its Excision by TDG in Mammalian DNA. Science 2011, 333(6047):1303-1307.

52. Ito S, Shen L, Dai Q, Wu SC, Collins LB, Swenberg JA, He C, Zhang Y: Tet Proteins Can Convert 5-Methylcytosine to 5-Formylcytosine and 5-Carboxylcytosine. Science 2011, 333(6047):1300-1303.

53. Maiti A, Drohat AC: Thymine DNA glycosylase can rapidly excise 5-formylcytosine and 5-carboxylcytosine: potential implications for active demethylation of CpG sites. J Biol Chem 2011, 286(41):35334-35338.

54. Valinluck V, Tsai HH, Rogstad DK, Burdzy A, Bird A, Sowers LC: Oxidative damage to methyl-CpG sequences inhibits the binding of the methylCpG binding domain (MBD) of methyl-CpG binding protein 2 (MeCP2). Nucleic Acids Res 2004, 32(14):4100-4108.

55. Yildirim O, Li R, Hung JH, Chen PB, Dong X, Ee LS, Weng Z, Rando OJ, Fazzio TG: Mbd3/NURD complex regulates expression of 5hydroxymethylcytosine marked genes in embryonic stem cells. Cell 2011, 147(7):1498-1510

56. Ficz G, Branco MR, Seisenberger S, Santos F, Krueger F, Hore TA, Marques CJ, Andrews S, Reik W: Dynamic regulation of 5-hydroxymethylcytosine in mouse ES cells and during differentiation. Nature 2011, 473(7347):398-402.

57. Yu M, Hon GC, Szulwach KE, Song CX, Zhang L, Kim A, Li X, Dai Q, Shen Y, Park $B$, et al: Base-resolution analysis of 5-hydroxymethylcytosine in the mammalian genome. Cell 2012, 149(6):1368-1380.

58. Patel JP, Gonen M, Fiqueroa ME, Fernandez H, Sun Z, Racevskis J, Van Vlierberghe P, Dolgalev I, Thomas S, Aminova O, et al: Prognostic relevance of integrated genetic profiling in acute myeloid leukemia. $N$ Engl I Med 2012, 366(12):1079-1089.

59. Paschka P, Schlenk RF, Gaidzik VI, Habdank M, Kronke J, Bullinger L, Spath D, Kayser S, Zucknick M, Gotze K, et al: IDH1 and IDH2 mutations are frequent genetic alterations in acute myeloid leukemia and confer adverse prognosis in cytogenetically normal acute myeloid leukemia with NPM1 mutation without FLT3 internal tandem duplication. $J$ Clin Oncol 2010, 28(22):3636-3643.
60. Chowdhury R, Yeoh KK, Tian YM, Hillringhaus L, Bagg EA, Rose NR, Leung IK, Li XS, Woon EC, Yang M, et al: The oncometabolite 2-hydroxyglutarate inhibits histone lysine demethylases. EMBO reports 2011, 12(5):463-469

61. Koivunen P, Lee S, Duncan CG, Lopez G, Lu G, Ramkissoon S, Losman JA Joensuu P, Bergmann U, Gross S, et al: Transformation by the (R)enantiomer of 2-hydroxyglutarate linked to EGLN activation. Nature 2012, 483(7390):484-488

62. Losman JA, Looper RE, Koivunen P, Lee S, Schneider RK, McMahon C, Cowley GS, Root DE, Ebert BL, Kaelin WG Jr: (R)-2-hydroxyglutarate is sufficient to promote leukemogenesis and its effects are reversible. Science 2013, 339(6127):1621-1625.

63. Suganuma T, Workman JL: Signals and combinatorial functions of histone modifications. Annu Rev Biochem 2011, 80:473-499.

64. Tan S, Davey CA: Nucleosome structural studies. Curr Opin Struct Biol 2011, 21(1):128-136

65. Neumann H, Hancock SM, Buning R, Routh A, Chapman L, Somers J, OwenHughes T, Van Noort J, Rhodes D, Chin JW: A method for genetically installing site-specific acetylation in recombinant histones defines the effects of H3 K56 acetylation. Molecular cell 2009, 36(1):153-163.

66. Muller BM, Jana L, Kasajima A, Lehmann A, Prinzler J, Budczies J, Winzer K, Dietel $M$, Weichert W, Denkert C: Differential expression of histone deacetylases HDAC1, 2 and 3 in human breast cancer - overexpression of HDAC2 and HDAC3 is associated with clinicopathological indicators of disease progression. BMC cancer 2013, 13(1):215.

67. Barbieri I, Cannizzaro E, Dawson MA: Bromodomains as therapeutic targets in cancer. Brief Funct Genomic 2013, 12(3):219-230.

68. Pirooznia SK, Elefant F: Targeting specific HATs for neurodegenerative disease treatment: translating basic biology to therapeutic possibilities. Front cellular neuroscience 2013, 7:30.

69. Jenuwein T, Allis CD: Translating the histone code. Science 2001, 293(5532):1074-1080.

70. Gardner KE, Allis CD, Strahl BD: OPERating ON Chromatin, a Colorful Language where Context Matters. J Mol Biol 2011, 409(1):36-46.

71. Di Croce L: Chromatin modifying activity of leukaemia associated fusion proteins. Hum Mol Genet 2005, 1:77-84.

72. Wang GG, Allis CD, Chi P: Chromatin remodeling and cancer, Part I: Covalent histone modifications. Trends Mol Med 2007, 13(9):363-372.

73. Minucci S, Nervi C, Lo Coco F, Pelicci PG: Histone deacetylases: a common molecular target for differentiation treatment of acute myeloid leukemias? Oncogene 2001, 20(24):3110-3115.

74. Tickenbrock L, Klein HU, Trento C, Hascher A, Gollner S, Baumer N, Kuss R, Agrawal S, Bug G, Serve H, et al: Increased HDAC1 deposition at hematopoietic promoters in $\mathrm{AML}$ and its association with patient survival. Leukemia research 2011, 35(5):620-625.

75. Timmermann S, Lehrmann H, Polesskaya A, Harel-Bellan A: Histone acetylation and disease. Cell Mol Life Sci 2001, 58(5-6):728-736.

76. Wang J, Hoshino T, Redner RL, Kajigaya S, Liu JM: ETO, fusion partner in t $(8 ; 21)$ acute myeloid leukemia, represses transcription by interaction with the human $\mathrm{N}-\mathrm{CoR} / \mathrm{mSin} 3 / \mathrm{HDAC} 1$ complex. Proc Natl Acad Sci USA 1998, 95(18):10860-10865.

77. Lin RJ, Nagy L, Inoue S, Shao W, Miller WH Jr, Evans RM: Role of the histone deacetylase complex in acute promyelocytic leukaemia. Nature 1998, 391(6669):811-814

78. Van Damme M, Crompot E, Meuleman N, Mineur P, Bron D, Lagneaux L, Stamatopoulos B: HDAC isoenzyme expression is deregulated in chronic lymphocytic leukemia B-cells and has a complex prognostic significance. Epigenetics 2012, 7(12):1403-1412.

79. Yu BD, Hess JL, Horning SE, Brown GA, Korsmeyer SJ: Altered Hox expression and segmental identity in MII-mutant mice. Nature 1995 378(6556):505-508.

80. Yagi H, Deguchi K, Aono A, Tani Y, Kishimoto T, Komori T: Growth disturbance in fetal liver hematopoiesis of Mll-mutant mice. Blood 1998, 92(1):108-117.

81. Ayton P, Sneddon SF, Palmer DB, Rosewell IR, Owen MJ, Young B, Presley R, Subramanian V: Truncation of the Mll gene in exon 5 by gene targeting leads to early preimplantation lethality of homozygous embryos. Genesis 2001, 30(4):201-212.

82. Ziemin-vanderPoel S, McCabe NR, Gill HJ, Espinosa R, Patel Y III, Harden A, Rubinelli P, Smith SD, LeBeau MM, Rowley JD, et al: Identification of a gene, MLL, that spans the breakpoint in 11 q23 translocations associated with human leukemias. Proc Natl Acad Sci USA 1991, 88(23):10735-10739. 
83. Milne TA, Briggs SD, Brock HW, Martin ME, Gibbs D, Allis CD, Hess JL: MLL targets SET domain methyltransferase activity to Hox gene promoters. Molecular cell 2002, 10(5):1107-1117.

84. Cosgrove MS, Patel A: Mixed lineage leukemia: a structure-function perspective of the MLL1 protein. The FEBS journal 2010, 277(8):1832-1842

85. Krivtsov AV, Armstrong SA: MLL translocations, histone modifications and leukaemia stem-cell development. Nat Rev Cancer 2007, 7(11):823-833

86. Marschalek R: Mechanisms of leukemogenesis by MLL fusion proteins. Br J Haematol 2011, 152(2):141-154

87. Lavau C, Du C, Thirman M, Zeleznik-Le N: Chromatin-related properties of CBP fused to MLL generate a myelodysplastic-like syndrome that evolves into myeloid leukemia. EMBO J 2000, 19(17):4655-4664.

88. Dobson CL, Warren AJ, Pannell R, Forster A, Lavenir I, Corral J, Smith AJ, Rabbitts TH: The mll-AF9 gene fusion in mice controls myeloproliferation and specifies acute myeloid leukaemogenesis. EMBO J 1999, 18(13):3564-3574.

89. DiMartino JF, Ayton PM, Chen EH, Naftzger CC, Young BD, Cleary ML: The AF10 leucine zipper is required for leukemic transformation of myeloid progenitors by MLL-AF10. Blood 2002, 99(10):3780-3785.

90. Okada Y, Feng Q, Lin Y, Jiang Q, Li Y, Coffield VM, Su L, Xu G, Zhang Y: hDOT1L links histone methylation to leukemogenesis. Cell 2005, 121(2):167-178.

91. Hublitz P, Albert M, Peters AH: Mechanisms of transcriptional repression by histone lysine methylation. Int J Dev Biol 2009, 53(2-3):335-354.

92. Nguyen AT, Taranova O, He J, Zhang Y: DOT1L, the H3K79 methyltransferase, is required for MLL-AF9-mediated leukemogenesis. Blood 2011, 117(25):6912-6922.

93. Monroe SC, Jo SY, Sanders DS, Basrur V, Elenitoba-Johnson KS, Slany RK, Hess JL: MLL-AF9 and MLL-ENL alter the dynamic association of transcriptional regulators with genes critical for leukemia. Exp Hematol 2011, 39(1):77-86-71-75.

94. Okada $Y$, Jiang $Q$, Lemieux M, Jeannotte L, Su L, Zhang Y: Leukaemic transformation by CALM-AF10 involves upregulation of Hoxa5 by hDOT1L. Nat Cell Biol 2006, 8(9):1017-1024.

95. He J, Nguyen AT, Zhang Y: KDM2b/JHDM1b, an H3K36me2-specific demethylase, is required for initiation and maintenance of acute myeloid leukemia. Blood 2011, 117(14):3869-3880.

96. Silverman LR, Demakos EP, Peterson BL, Kornblith AB, Holland JC, OdchimarReissig R, Stone RM, Nelson D, Powell BL, DeCastro CM, et al: Randomized controlled trial of azacitidine in patients with the myelodysplastic syndrome: a study of the cancer and leukemia group B. Int J Clin Oncol 2002, 20(10):2429-2440.

97. Kantarjian H, Issa JP, Rosenfeld CS, Bennett JM, Albitar M, DiPersio J, Klimek V, Slack J, De Castro C, Ravandi F, et al: Decitabine improves patient outcomes in myelodysplastic syndromes: results of a phase III randomized study. Cancer 2006, 106(8):1794-1803.

98. Chu BF, Karpenko MJ, Liu Z, Aimiuwu J, Villalona-Calero MA, Chan KK, Grever MR, Otterson GA: Phase I study of 5-aza-2'-deoxycytidine in combination with valproic acid in non-small-cell lung cancer. Cancer Chemother Pharmacol 2013, 71(1):115-121.

99. Cogdill AP, Frederick DT, Cooper ZA, Garber HR, Ferrone CR, Fiedler A, Rosenberg L, Thayer SP, Warshaw AL, Wargo JA: Targeting the MAGE A3 antigen in pancreatic cancer. Surgery 2012, 152(3 Suppl 1):S13-18.

100. Schneider-Stock R, Diab-Assef M, Rohrbeck A, Foltzer-Jourdainne C, Boltze C, Hartig R, Schonfeld P, Roessner A, Gali-Muhtasib H: 5-Aza-cytidine is a potent inhibitor of DNA methyltransferase $3 a$ and induces apoptosis in HCT-116 colon cancer cells via Gadd45- and p53-dependent mechanisms. J Pharmacol Exp Ther 2005, 312(2):525-536.

101. Kelly TK, De Carvalho DD, Jones PA: Epigenetic modifications as therapeutic targets. Nature biotechnology 2010, 28(10):1069-1078.

102. McCabe MT, Brandes JC, Vertino PM: Cancer DNA methylation: molecular mechanisms and clinical implications. Clin Cancer Res 2009, 15(12):3927-3937

103. Christman JK: 5-Azacytidine and 5-aza-2'-deoxycytidine as inhibitors of DNA methylation: mechanistic studies and their implications for cancer therapy. Oncogene 2002, 21(35):5483-5495.

104. Derissen EJ, Beijnen $\mathrm{JH}$, Schellens $\mathrm{JH}$ : Concise drug review: azacitidine and decitabine. Oncologist 2013, 18(5):619-624.

105. Prince HM, Bishton MJ, Harrison SJ: Clinical studies of histone deacetylase inhibitors. Clin Cancer Res 2009, 15(12):3958-3969.
106. Yang X-J, Seto E: The Rpd3/Hda1 family of lysine deacetylases: from bacteria and yeast to mice and men. Nat Rev Mol Cell Biol 2008, 9(3):206-218.

107. Mai $A$ : The therapeutic uses of chromatin-modifying agents. Expert Opin Ther Targets 2007, 11(6):835-851.

108. Federico $M$, Bagella $L$ : Histone deacetylase inhibitors in the treatment of hematological malignancies and solid tumors. J Biomed Biotechnol 2011, 2011:475641.

109. Balasubramanyam K, Varier RA, Altaf M, Swaminathan V, Siddappa NB, Ranga U, Kundu TK: Curcumin, a novel p300/CREB-binding proteinspecific inhibitor of acetyltransferase, represses the acetylation of histone/nonhistone proteins and histone acetyltransferase-dependent chromatin transcription. J Biol Chem 2004, 279(49):51163-51171.

110. Balasubramanyam K, Altaf M, Varier RA, Swaminathan V, Ravindran A, Sadhale PP, Kundu TK: Polyisoprenylated benzophenone, garcinol, a natural histone acetyltransferase inhibitor, represses chromatin transcription and alters global gene expression. J Biol Chem 2004, 279(32):33716-33726.

111. Sun $Y$, Jiang $X$, Chen S, Price BD: Inhibition of histone acetyltransferase activity by anacardic acid sensitizes tumor cells to ionizing radiation. FEBS Lett 2006, 580(18):4353-4356.

doi:10.1186/1756-8722-6-57

Cite this article as: Gutierrez and Romero-Oliva: Epigenetic changes: a common theme in acute myelogenous leukemogenesis. Journal of Hematology \& Oncology 2013 6:57.

\section{Submit your next manuscript to BioMed Central and take full advantage of:}

- Convenient online submission

- Thorough peer review

- No space constraints or color figure charges

- Immediate publication on acceptance

- Inclusion in PubMed, CAS, Scopus and Google Scholar

- Research which is freely available for redistribution

Submit your manuscript at www.biomedcentral.com/submit
C) Biomed Central 